TRANSFER

Reception Studies

\title{
Gorzkie łzy nieznośnych dzieci w wersji polskiej, czyli o motywie płaczu w tłumaczeniach zbiorku Struwwelpeter Heinricha Hoffmanna
}

\section{The bitter tears of unbearable children in the Polish version or the crying theme in the translations of Heinrich Hoffmann's Struwwelpeter}

\footnotetext{
Abstract: The paper makes a comparative analysis on the theme of tears in three Polish translations of Heinrich Hoffmann's Struwwelpeter. The aim is to interpret the collected data (words related to the theme of tears appear significantly more often in all translations than in the original) and to compare them with the strategies of Polish translators described in earlier research, especially in the studies of Joanna Dybiec-Gajer. The choices made by translators in the field of lexis and syntax, as well as the applied amplifications and transformations, indicate a close connection of the contexts in which the theme of tears appears with the general features of the translation / adaptation, in particular with the tendency to emphasize the didactic function or to encourage reading for pleasure. While, on the other hand, there is an indication the choices made deal with projected reactions of the child reader's fear, through empathy to non-serious reading. The article also presents briefly the history of Struwwelpeter's publications in Poland in the 160 years since the first, anonymous edition of the book entitled Złota różdżka, as well as the most important threads of Polish research on the work. The interpretations of Struwwelpeter and Złota różdżka that have appeared in Polish sources and literary criticism are also mentioned as well as the problem of identifying the Polish translation (which is in fact an adaptation) with the original.

Keywords: Struwwelpeter, Złota różdżka, translation, adaptation, reading for pleasure, didacticism, empathy.
} 
W roku 2018 upłynęło 160 lat od wydania Złotej różdżki - pierwszej polskiej wersji zbiorku Struwwelpeter Heinricha Hoffmanna. Nazywany w swej ojczyźnie „najbardziej popularną wśród niemieckich książek dla dzieci”, tomik wierszowanych narracji o katastrofalnych następstwach dziecięcego nieposłuszeństwa i nierozwagi budzi od dawna zarówno zachwyty, jak i głosy krytyczne, stanowiąc przy tym kanoniczny składnik wyobraźni zbiorowej Niemców2 ${ }^{2}$. Opowiastki są drastyczne, beztrosko skazują dziecięcych bohaterów na śmierć lub okaleczenie; autor opatrzył je przy tym prostymi, dobitnymi ilustracjami, które nierzadko intensyfikują, czasem modyfikują, przekaz tekstu, a ich znacząca liczba i doniosłość dla ogólnej wymowy utworu każą uznać Struwwelpetera za wczesny picture-book.

Wielka poczytność książeczki bywa tłumaczona śmiałością obrazowania, potoczystym rytmem wersów, siłą dydaktycznego przesłania ${ }^{3}$, ale cechą zarówno opowiastek, jak i obrazków jest uderzająca przesada i groteskowość, dlatego przekonująco brzmią także głosy proponujące lekturę z przymrużeniem oka, poszukujące w utworze elementów subtelnej parodii. Pedagog Andreas Flitner tak na przykład tłumaczy fenomen popularności Hoffmanna, rekonstruując przy tym dziecięcą interpretację Struwwelpetera:

Nie można orzec jednoznacznie, co zdecydowało o bezprecedensowym sukcesie tej książki, o jej ponad pięciuset wydaniach, o jej popularności, która trwa do dziś i przyćmiła wszelkie oceny krytyczne. Czy to prostota wersów i moralizatorskie obrazki? Czy, jak w przypadku baśni, możliwość rzutowania własnych problemów i pragnień na opowieści? Czy raczej mściwość, z jaką dzieci zadają swoim rodzicom makabryczne kary: macie teraz za swoje wrzaski i pouczenia! Nie tylko potłuczoną porcelanę i mokre ubrania, ale na koniec tylko kupkę popiołu, krzyż cmentarny lub czerwoną kropkę na niebie, parasol, na którym wasze dziecko odlatuje w nieznane!4

\section{Struwwelpeter w Polsce}

Rocznica pierwszego wydania polskiej wersji książeczki Hoffmanna nie przeszła bez echa - fakt ten został w naszym kraju zauważony i wywołał

1 Andreas Flitner, Konrad, sprach die Frau Mama... Über Erziehung and Nicht-Erziehung (Weinheim/Basel: Beltz Taschenbuch, 2009), 5.

2 Por. Constanze Cercenac-Lecomte, „Der Struwwelpeter”, w Deutsche Erinnerungsorte, t. 3, red. Etienne François i Hagen Schulze (München: Verlag C.H. Beck, 2001), 136-137.

3 Por. Cercenac-Lecomte, „Der Struwwelpeter”, 122.

4 Flitner, Konrad, sprach die Frau Mama..., 9. Jeśli chodzi o wspomnianą przez autora liczbę wydań - ponad pięćset - jest chyba mocno zaniżona. Constanze Cernac-Lecomte podaje liczbę 539 wydań do roku 1925, gdy prawa autorskie do książeczki wygasły. Liczbę wydrukowanych dotąd egzemplarzy szacuje natomiast jako mieszczącą się w granicach od 15 do 25 milionów. Por. Cercenac-Lecomte, „Der Struwwelpeter”, 128. 
nową falę zainteresowania tym - równie sławnym, jak kontrowersyjnym utworem. Jubileusz uświetniło wydanie interdyscyplinarnej monografii Joanny Dybiec-Gajer Złota różdżka - od ksiq̨żki dla dzieci po dreszczowiec raczej dla dorosłych, ukazało się także nowe wydanie wierszyków w formie awangardowej książki obrazkowej, w której opowiastki Hoffmanna zostały po części umieszczone we współczesnych, często jednoznacznie polskich realiach ${ }^{5}$.

Tytułowy bohater Struwwelpetera był wprawdzie w tłumaczeniach znany jako „Staś Straszydło”, „Piotruś Rozczochraniec” i „Piotruś Czupiradło", ale w Polsce jego imię nie jest na ogół traktowane jak tytuł całego zbiorku', który od początku był publikowany jako Złota różdżka (pierwotnie w zapisie rószczka, czasem jeszcze powracającym w reprintach wydań dziewiętnastowiecznych), i do tradycji tej sięga także wspomniana najnowsza adaptacja.

Pierwsza polska wersja Struwwelpetera, wydana anonimowo, przez dłuższy czas nie była kojarzona ze swoim pierwowzorem. 0 początkach obecności utworu Hoffmanna w Polsce pisze Janusz Dunin:

Struwwelpeter nie występował w Polsce pod własnym imieniem i nie znano nazwiska jego autora. Należał do tej masy XIX-wiecznych książek dla dzieci, które na teren polski docierały z zagranicy wraz z ilustracjami i tutaj dopiero dorabiano do nich polskie teksty, czasem zgodne z pierwowzorem, czasem nie, inspirowane jedynie istniejącymi już obrazkami. Spolszczano nie tylko imiona bohaterów, ale też nie podawano nazwisk ilustratorów ani tym bardziej autorów ${ }^{7}$.

Złota różdżka została opublikowana w Petersburgu, najprawdopodobniej po raz pierwszy w roku 1858 (choć mogło istnieć niezachowane wydanie wcześniejsze, pojawiające się w katalogach z roku 1854)8, w oficynie Bolesława Maurycego Wolffa, polsko-rosyjskiego wydawcy, który w latach czterdziestych odbył praktykę w Niemczech, gdzie, jak wolno przypuszczać, zetknął się z książeczką Struwwelpeter i stał się świadkiem jej spektakularnego sukcesu wydawniczego. Przed pierwszą wojną światową Złota różdżka miała, jak stwierdza Janusz Dunin, kilka edycji i wiele dodruków, toteż jej

5 Heinrich Hoffmann, Złota różdżka, czyli bajki dla niegrzecznych dzieci, il. Justyna Sokołowska, adaptacja Anna Bańkowska, Karolina Iwaszkiewicz, Zuzanna Naczyńska, Adam Pluszka, Marcin Wróbel i Michał Rusinek (Warszawa: Egmont Polska, 2017).

$6 \quad$ Z jednym wyjątkiem - dwujęzycznej edycji Piotruś Rozczochraniec w przekładzie Lecha Konopińskiego, opublikowanej w niemieckim wydawnictwie Edition Tintenfass w roku 2015.

7 Janusz Dunin, „Struwwelpeter, Stepka-Rastrepka czyli Złota Różdżka. Z dziejów kariery jednej książki", w Heinrich Hoffmann, Złota rószczka (Łódź: Verso, 2003, reprint wyd. czwartego: nakładem Tow. M.C. Wolff, Petersburg, 1883), 9.

8 Por. Dunin, „Struwwelpeter, Stepka-Rastrepka czyli Złota Różdżka. Z dziejów kariery jednej książki", 17. 
zasięg na terenie zaboru rosyjskiego oraz Galicji może być uważany za bardzo rozległy, choć dziś książeczki te to prawdziwe białe kruki. W ówczesnych edycjach pomijano zarówno nazwisko Heinricha Hoffmanna, jak i ilustratora, nie identyfikowano w nich również twórcy polskiego tekstu. Mimo pewnych wątpliwości przyjmuje się dziś, że autorem tego dość swobodnego tłumaczenia był warszawski literat i dziennikarz Wacław Szymanowski. Co bardzo ciekawe, Janusz Dunin odkrył i dobrze udokumentował wpływ, jaki na polską wersję wywarło wcześniejsze anonimowe tłumaczenie rosyjskie, opublikowane w roku 1849, zatytułowane Стёnка-растрёnка (Stiopkarastriopka). Dunin uważa, że pierwsze (i przez 150 lat jedyne dostępne) tłumaczenie Struwwelpetera na język polski zostało w rzeczywistości dokonane z rosyjskiego ${ }^{9}$. Także ryciny Złotej różdżki zapożyczono z wersji rosyjskiej (warstwę ilustracyjną poddając przy tym polonizacji); nie skorzystano z rysunków Heinricha Hoffmanna, reprodukowanych do dziś w Niemczech. Wzorem Stiopki-rastriopki pominięto w Złotej różdżce także dwa utwory prolog i historyjkę myśliwego uciekającego przed uzbrojonym zającem (Die Geschichte vom wilden Jäger).

Kalendarium sporządzone przez Joannę Dybiec-Gajer odnotowuje dwa międzywojenne wydania Złotej różdżki z nowymi ilustracjami Bogdana Nowakowskiego - w roku 1922 i 1933. Po drugiej wojnie światowej zbiorek ukazał się w Polsce dopiero w roku 1987 - był to reprint edycji z roku 1933. Kolejne edycje Złotej różdżki w przekładzie Szymanowskiego to reprinty wydań sprzed pierwszej wojny światowej. Łącznie ukazały się trzy: pierwszy wydał Stentor w 1993 roku, w roku 2003 ukazał się reprint czwartego wydania (z roku 1883) oficyny Wolffa, przygotowany i opatrzony obszernym komentarzem przez Janusza Dunina, nader zasłużonego dla polskich badań nad Struwwelpeterem. Jest to także pierwsze polskie wydanie, w którym nazwisko Hoffmanna umieszczono na okładce ${ }^{10}$. Ostatnio Złota różdżka ukazała się w 2018 roku, tym razem jako reprint trzeciego wydania Wolffa, z posłowiem Łukasza Kozaka11.

Druga dekada XXI stulecia przyniosła także dwa zupełnie nowe tłumaczenia Struwwelpetera na język polski. Pierwsze z nich ukazało się $\mathrm{w}$ formie edycji dwujęzycznej w Niemczech w wydawnictwie Edition Tintenfass w roku 2015 (i ponownie w 2019). Przekład opublikowano pod tytułem Pio-

9 Dunin, „Struwwelpeter, Stepka-Rastrepka czyli Złota Różdżka. Z dziejów kariery jednej książki."

10 Joanna Dybiec-Gajer, Złota różdżka - od książki dla dzieci po dreszczowiec raczej dla dorosłych (Kraków: Tertium, 2017), 184-185.

11 Hoffmann, Złota rószczka. Wydawca deklaruje, że trzecie wydanie Wolffa pochodzi z roku 1892, co pozostaje w oczywistej sprzeczności w faktem, że wydanie czwarte tejże oficyny Wolffa datowane jest na rok 1883, por. przypis 7. 
truś Rozczochraniec. Wesołe historyjki i zabawne rysunki Heinricha Hoffmanna; jego autorem jest Lech Konopiński. Tłumaczenie to, w przedmowie niemieckiego badacza, Waltera Sauera, nazwane „kongenialnym” ${ }^{12}$, wydaje się pod wieloma względami najbardziej ekwiwalentne formalnie dzieli z oryginałem liczbę i układ utworów, ma analogiczny tytuł i podtytuł (to jedyna polska wersja Struwwelpetera, w której cały zbiorek jest zatytułowany tak samo, jak pierwsza opowieść), opatrzono go także - po raz pierwszy w Polsce - oryginalnymi ilustracjami Hoffmanna.

Rok 2017 przyniósł ostatnią, jak dotąd, polską wersję Struwwelpetera; ukazała się w wydawnictwie Egmont pod utrwalonym, choć najzupełniej obcym oryginałowi, tytułem Złota różdżka. Decyzja ta może sugerować, że w przeciwieństwie do Lecha Konopińskiego - liczni autorzy „nowej” Złotej różdżki chcieli się w swojej publikacji nie tylko odnieść do niemieckiego oryginału, lecz także podjąć dialog z polską tradycją jego przekładów, a pośrednio także interpretacji. Strategie przyjęte przez poszczególnych twórców były różne, ale - choć w kilku przypadkach nowe wersje wierszyków uwspółcześniają i polonizują realia, a ponadto otwarcie mówi się o „adaptacji” tekstu, konsekwentnie unikając wyrazu "tłumaczenie” - Heinrich Hoffmann został wskazany na stronie tytułowej jako autor ${ }^{13}$. „Nowa” Złota różdżka jest także śmiałą, atrakcyjną wizualnie książką obrazkową, a poniekąd i książką-zabawką przeznaczoną do ludycznych manipulacji (ze względu na wycięty w dodatkowej karcie po wyklejce otwór w kształcie czaszki i skrzyżowanych piszczeli, przez który „zaglądamy” do wnętrza). Projekt graficzny Justyny Sokołowskiej powstał wcześniej niż polski tekst, złożony z różniących się od siebie pod wieloma względami przekładów/adaptacji. Ich autorami są: Anna Bańkowska (Piotruś Czupiradło, Straszna historia o Hani i zapałkach), Karolina Iwaszkiewicz (O złym Szymku, O Filipie, co się bujał), Zuzanna Naczyńska (Opowieść o małych czarnych chłopcach, Opowieść o Jacku Wniebogapku), Adam Pluszka (O groźnym myśliwym, O latajqcym Robercie) oraz Marcin Wróbel (O Konradzie, co obgryzał paznokcie, o Kacperku, co wzgardził zupq). Współtwórcą książki jest ponadto Michał Rusinek, autor wstępu i tłumacz prologu. „Nowa” Złota różdżka zawiera wszystkie małe narracje, składające się na niemieckiego Struwwelpetera, ma

12 Walter Sauer, „Przedmowa”, w Heinrich Hoffmann, Piotruś Rozczochraniec. Wesołe historyjki i zabawne rysunki Heinricha Hoffmanna, przeł. Lech Konopiński (Heidelberg: Edition Tintenfass, 2015), 5.

13 Na temat zróżnicowania strategii (przekład/adaptacja) twórców „nowej” Złotej różdżki oraz relacji ich tekstów do oryginału i pierwszego polskiego tłumaczenia por. Joanna Dybiec-Gajer, „Wiersz dla dzieci w przekładzie profesjonalnym i amatorskim - «Der Wilde Jäger» ze zbioru «Struwwelpeter» («Złota różdżka») po polsku”, Orbis Linguarum, nr 48 (2018): 246. 
natomiast zmodyfikowaną („postawioną na głowie”) kompozycję, na ostatniej stronie okładki zamieszczono bowiem prolog, w którym grzecznym dzieciom obiecuje się cudowny bożonarodzeniowy prezent: książkę z obrazkami.

Sytuacja książeczki Hoffmanna w Polsce jest pełna paradoksów: mamy do czynienia z serią przekładową, co nie jest częstym zjawiskiem na gruncie szybko zmieniającej się literatury dla dzieci i dotyczy raczej utworów kanonicznych, niejednokrotnie obecnych na listach lektur szkolnych, regularnie wznawianych, mających duże nakłady i znanych wielu czytelnikom. Nie jest tak jednak w przypadku tłumaczeń i adaptacji Struwwelpetera, a dodatkowo sytuację komplikuje fakt, że obecność tych utworów w Polsce nie ma już oczywistego związku z dziecięcą publicznością literacką. „Stara” Złota różdżka, o czym świadczy choćby forma niskonakładowych wydań (reprintów edycji dziewiętnastowiecznych) publikowanych przez wydawnictwa niezwiązane na ogół z rynkiem książki dla dzieci, trafia przede wszystkim do wąskiego kręgu wykształconych dorosłych. Utwór ten jest jednak znakomicie znany historykom literatury i kultury, powraca we wspomnieniach wybitnych Polaków, pamiętają o nim autorzy opracowań naukowych, zwłaszcza z zakresu historii polskiej literatury dziecięcej. Co ciekawe, ze względu na opisane wyżej uwarunkowania związane z trwającym długo zatarciem autorstwa, Złota różdżka jest często traktowana niemal jak polski tekst, ewentualnie utwór luźno inspirowany obcym pierwowzorem. Dla przykładu Jerzy Cieślikowski, choć miał świadomość związku Złotej różdżki z niemieckim zbiorkiem Hoffmanna, zdecydował się umieścić jej fragmenty $\mathrm{w}$ antologii zawierającej poza tym wyłącznie polską poezję dla dzieci, a dodatkowo nazwisko Hoffmanna podał tylko we Wstępie ${ }^{14}$, traktując w zasadzie Złotq różdżkę jak dzieło anonimowe ${ }^{15}$.

Drugie i trzecie spolszczenie Struwwelpetera dzieli od pierwszego okres ponad 150 lat, powstały natomiast w bardzo krótkim okresie, wyznaczonym datami 2015 roku (Piotruś Rozczochraniec) i 2017 roku („nowa” Złota różdżka), przekład Konopińskiego, wydany w Niemczech, jest książką bardzo trudno osiągalną, nieobecną nawet w najważniejszych polskich bibliotekach i sprowadzaną przez niektóre księgarnie na zamówienie (z pewnością nielicznych) czytelników, wśród których dominują, jak przypuszczam, badacze literatury dla dzieci i przekładoznawcy. Jedynie „nowa” Złota różdżka ma wyraźne cechy książki dziecięcej i jest dostępna w wielu księgarniach i bibliotekach, a zatem mogłaby dotrzeć do szerszych grup małych czytelników, o ile pokona opory dorosłych nabywców i bibliotekarzy.

14 Jerzy Cieślikowski, „Wstęp”, w Antologia poezji dziecięcej, oprac. Jerzy Cieślikowski (Wrocław: Zakład Narodowy im. Ossolińskich, 1981), XLIX-L.

15 Antologia poezji dziecięcej, oprac. Jerzy Cieślikowski (Wrocław: Zakład Narodowy im. Ossolińskich, 1981), s . 57-59. 
„Stara” Złota różdżka i Piotruś Rozczochraniec wpisują się w charakterystyczny dla wielu serii przekładowych porządek odczytań, o którym pisze Eliza Pieciul-Karmińska, cytując Paula Bensimona: pierwszy przekład jest na ogół formą „aklimatyzacji”, stawia sobie za cel naturalizację tekstu źródłowego, drugi przekład natomiast jest zwykle „wrażliwy na literę oryginału”, zdecydowanie bardziej wierny i staranny filologicznie ${ }^{16}$. „Nowa” Złota różdżka to ponownie dosyć swobodna adaptacja, choć wielość tłumaczy i zróżnicowanie ich decyzji znacząco komplikują sytuację.

Jeśli idzie o recepcję książeczki Hoffmanna, głosy polskich uczonych na temat zbiorku rozkładają się na dwa rozłączne, jeśli nie wręcz przeciwstawne, nurty. Pierwszy reprezentują rzecznicy książeczki, chwalący ją za świeżość spojrzenia na ilustracje, problematyzowanie dydaktyzmu, przewrotny humor, odważną grę z konwencją. Są to badacze czytający utwór w Bachtinowskiej dwugłosowej perspektywie i dostrzegający w dziełku parodię opresywnej pedagogiki, ironiczny dystans, atrakcyjną dla dziecka zabawę w groteskową przesadę, która pozwala rozbroić śmiechem strach przed przemocą ze strony dorosłych. Tę ścieżkę interpretacji otwiera Janusz Dunin:

Ważne i nowe było też potraktowanie tematu humorystycznie, dziś powiedzielibyśmy - z przymrużeniem oka. Wbrew temu, co dziś możemy sądzić, teksty nie brały opisywanych kar dostatecznie serio, w istocie nie chciały straszyć dzieci, [lecz] bawić. W tym sensie znaczna część przyszłej literatury dziecięcej, wraz z Tuwimem i Brzechwą, stanowiła kontynuację myśli Hoffmanna, który przeciwstawił się niesłychanie solennemu tonowi dydaktycznemu wcześniejszej literatury dla małego odbiorcy ${ }^{17}$.

Podobnie sądzi Joanna Dybiec-Gajer, przywołując aprobatywnie badania amerykańskie:

Wśród interpretacji wyrosłych na gruncie przekładoznawczym bardzo trafnie istotę utworu charakteryzuje, moim zdaniem, John Daniel Stahl. Dostrzega pouczającą i ostrzegającą wymowę historyjek, podkreśla jednak, że są one również „przepełnione połączeniem humoru, ekstrawagancji i pragmatyki, podszyte nutą kpiny [...]. Przez utwór przewija się nurt anarchicznej energii, która nie zostaje całkowicie zniesiona przez moralizatorskie ramy utworu" 18 .

16 Eliza Pieciul-Karmińska, „Polska seria przekładowa «Dziadka do orzechów i króla myszy» E.T.A. Hoffmanna", Studia Interkulturowe, nr 8 (2015): 58-59.

17 Dunin, „Struwwelpeter, Stepka-Rastrepka czyli Złota Różdżka. Z dziejów kariery jednej książki", 26.

18 Joanna Dybiec-Gajer, „Wiersz dla dzieci w przekładzie profesjonalnym i amatorskim «Der Wilde Jäger» ze zbioru «Struwwelpeter» («Złota różdżka») po polsku”, 139. Autorka cytuje tekst Johna Daniela Stahla: John Daniel Stahl, Mark Twain's „Slovenly Peter” in the Context of Twain and German Culture, w The Translation of Children's Literature: A Reader, red. Gillian Lethey (Clevedon: Multilingual Matters, 2006), 217. 
W zbliżonym tonie, choć ostrożniej, wypowiada się Magdalena Jonca, zauważając dwoistość odczytań Struwwelpetera na gruncie badań zachodnich; stwierdza, że współczesne literaturoznawstwo

eksponuje rażącą niewspółmierność między okrutnymi formami karania krnąbrnych dziatek a ich wyolbrzymianymi przewinieniami. Ten drugi trop każe ujmować tekst w kategoriach humorystycznych, makabryczno-groteskowych, rozpoznawalnych przez nieletniego odbiorcę, pobudzanego tym samym do zabawy, do gry z konwencją ${ }^{19}$.

Z drugiej strony mamy też w Polsce znacznie starszą tradycję czytania Złotej różdżki (i, niejako wtórnie, Struwwelpetera) jako reliktu przerażającej „czarnej pedagogiki”, skrajnie opresywnego utworu podporządkowanego intencji moralizatorskiej, uciekającej się do zastraszania i symbolicznego poniżania dziecięcego czytelnika ${ }^{20}$. Podobny, jednoznacznie krytyczny odbiór oryginalnej książeczki w myśli niemieckiej jest rzadki, choć i w swojej ojczyźnie Struwwelpeter bywał w podobnym tonie piętnowany - nurt ostrej krytyki rozpoczął się na fali kontestacji roku 1968, w zasadzie wyłącznie w RFN, ustał natomiast po ponownym zjednoczeniu Niemiec. Obecnie utwór Hoffmanna znowu cieszy się wielkim powodzeniem, co wyraża się na przykład w licznych przekładach na dialekty21.

Obok otwartej krytyki mamy w Polsce próby wypracowania stanowiska pośredniego. W taki sposób - choć znacznie bliższy drugiemu niż pierwszemu z zaprezentowanych stanowisk - myśli o książce Hoffmanna Michał Rusinek, pisząc we wstępie do „nowej” Złotej różdżki:

Satyra piętnuje rzeczywistość, by poprawić to, co złe czy błędne. I takie było przecież zamierzenie Hoffmanna: napiętnować dziecięce przywary i nakłonić niegrzeczne dzieci do zmiany postępowania [...]. Główną przyczyną popularności tej książki od pierwszego jej wydania była nie tyle jej wymowa pedagogiczna czy nawet satyryczna, lecz właśnie jej niezamierzony purnonsens: „okrucieństwa” kar wymierzanych małym przestępcom nie da się traktować równie poważnie, jak okrucieństwa bajek braci Grimm. Okrucieństwo opowiedziane językiem prościutkiej rymowanki

19 Magdalena Jonca, „Historie o Stasiu Straszydle i innych rozrabiakach (Heinrich Hoffmann: «Złota różdżka»)", w Arcydzieła literatury niemieckojęzycznej. Szkice, komentarze, interpretacje, red. Edward Białek i Grzegorz Kowal (Wrocław: Oficyna Wydawnicza Atut, 2011), 9-10.

20 Por. Julian Tuwim, „Michaś i zupa”, w Julian Tuwim, Cicer cum caule, czyli groch z kapusta (Warszawa: Iskry, 2009), 357-360; Grzegorz Leszczyński, Książki pierwsze. Książki ostatnie? Literatura dla dzieci i młodzieży wobec wyzwań nowoczesności (Warszawa: Wydawnictwo Stowarzyszenia Bibliotekarzy Polskich, 2012), 16; Katarzyna Slany, Groza w literaturze dziecięcej. Od Grimmów do Gaimana (Kraków: Wydawnictwo Naukowe Uniwersytetu Pedagogicznego, 2016), 252-255; Małgorzata Cackowska, „0 starej «Złotej rószczce» i nowej «Złotej różdżce, czyli bajkach dla niegrzecznych dzieci»", Kultura Liberalna, nr 35 (451) (2017), https://kulturaliberalna.pl/2017/08/29/malgorzata-cackowska-o-zlotejrozdzce-kl-dzieciom/.

21 Por. Carcenac-Lecomte, „Der Struwwelpeter”, 129. 
i nadmiernie wyolbrzymione staje się własną karykaturą, nie wywołuje trwogi, ale śmieszy. Choć nie było to zamierzeniem autora, „Złotej różdżce” bliżej - zwłaszcza dzisiaj - do książek Edwarda Goreya, który uważał, że tylko purnonsens podszyty makabrą jest wart uwagi zarówno pod względem estetycznym, jak egzystencjalnym ${ }^{22}$.

Rusinek, podobnie jak Dunin i Dybiec-Gajer, proponuje kontekst czarnego humoru i zachęca do lektury wywrotowej, podszytej kpiną - sądzi jednak, w przeciwieństwie do obojga wymienionych badaczy, że jest to lektura subwersywna, sprzeczna z pierwotną intencją tekstu. Z jego stanowiskiem polemizuje Eliza Pieciul-Karmińska, podkreślając przede wszystkim problem zauważalny w wielu polskich wypowiedziach na temat Złotej różdżki: szereg badaczy utożsamia ten utwór z niemieckim Struwwelpeterem, uznając cechy polskiego tekstu za efekt autorskich zamierzeń Heinricha Hoffmanna ${ }^{23}$. Stanowisko Rusinka nie jest odosobnionym przykładem, lecz stanowi wyraz ogólniejszej tendencji: istnieje ścisły związek między interpretacją utworu Hoffmanna a kontekstem, w którym hipotezy interpretacyjne są formułowane. Inaczej czytają utwór poloniści, obcujący wyłącznie ze „starą” Złotą różdżką, inaczej germaniści, przekładoznawcy, komparatyści, w centrum refleksji umieszczający Struwwelpetera. Można przypuszczać, że rysująca się na gruncie polskim ciągłość odczytań w duchu pedagogiki represji wynika z sięgania do odmiennej niż na Zachodzie literatury przedmiotu, ale nie w pełni wyjaśnimy obserwowane fakty interpretacyjne za pomocą tej hipotezy ${ }^{24}$. W rzeczywistości kluczową rolę odgrywa tu sam tekst w przekładzie na język polski - sensy Złotej różdżki i Struwwelpetera są w oczywisty sposób nieidentyczne, ale fakt ten od dawna uchodził uwadze wielu czytelników.

Zjawisko to dostrzegła Joanna Dybiec-Gajer, która zarówno w artykułach problemowych, jak i porównawczych ${ }^{25}$, a także w recenzjach ${ }^{26}$, zwracała

22 Michał Rusinek, „Wstęp”, w Heinrich Hoffmann, Złota różdżka, czyli bajki dla niegrzecznych dzieci, 6.

23 Eliza Pieciul-Karmińska, „O niektórych aspektach tradycji czytania i przekładania literatury dla dzieci. Na kanwie recenzji książki Joanny Dybiec-Gajer «Złota różdżka - od książki dla dzieci po dreszczowiec raczej dla dorosłych»", Porównania, nr 1 (2018): 391, DOI: 10.14746/por.2018.1.22.

24 Skądinąd niebezpodstawnej: w Polsce nie zdajemy sobie na ogół sprawy, że w dziewiętnastym wieku w Niemczech Struwwelpeter bywał krytykowany jako książka wywrotowa, a jej autor znany był z liberalnych poglądów. Por. Joanna Dybiec-Gajer, „Złota różdżka - od książki dla dzieci po dreszczowiec raczej dla dorosłych", 150-151.

25 Joanna Dybiec-Gajer, „Lokalizacja a przekład dla dzieci: jak utwory strasznieją i mądrzeją w tłumaczeniu, na przykładzie «Stasia Straszydło» i «Mądrej Myszy»", w Między tekstem a kulturq. Z zagadnień przekładoznawstwa, red. Aleksandra R. Knapik i Piotr P. Chruszczewski (San Diego: Æ Academic Publishing, 2018).

26 Joanna Dybiec-Gajer, „Implikacje utożsamiania przekładu z oryginałem. Polemika z interpretacją złotej różdżki w książce katarzyny slany groza w literaturze dziecięcej. Od grim- 
wielokrotnie uwagę na fakt, że Złotą różdżkę należy uznać raczej za adaptację niż tłumaczenie. Autorka podkreśla uderzającą cechę tej pierwszej polskiej wersji: jest nią amplifikacja, wyrażająca się w celowym „dodawaniu” do sytuacji opisanych w oryginale nowych kar, a także eksplicytnie wyrażonych „morałów” (w rodzaju słynnego „Kto nie je zupy, ten umrzeć musi”) oraz odniesień religijnych („Bo kara Boża tam, gdzie swawola: nie ma Grzegorza ni parasola!"). Bohaterowie w oryginale padają ofiarą własnych błędów (Paulinchen spalona na skutek zabawy ogniem, Robert porwany przez nawałnicę przez nieostrożność), doświadczają zemsty ze strony prześladowanych przez siebie istot (Friederich ugryziony przez psa) lub dostają nauczkę od na poły fantastycznych postaci o cechach potworów (Konrad, któremu krawiec obciął palce). W polskiej wersji ich prześladowcami stają się dodatkowo okrutni lub cyniczni rodzice, przy czym ta właściwość przekładu nie da się wyjaśnić zapośredniczeniem przez tekst rosyjski, który - choć również wyolbrzymiający w pewnej mierze właściwości oryginału - jest mu pod tym względem znacznie wierniejszy. Podobną - dydaktyczną i ujednoznaczniającą - intencję można przypisać także celowym pominięciom (widocznym tym razem zarówno w tekście polskim, jak i wcześniejszym rosyjskim): dotyczy to zwłaszcza braku komicznego utworu w stylu świata-na-opak, Die Geschichte vom wilden Jäger, w którym postacią okrutną i skompromitowaną jest dorosły. Joanna Dybiec-Gajer zwraca także uwagę na dwuznaczność niemieckich ilustracji (Struwwelpeter przedstawiony na piedestale, groteskowa i odrealniająca sztywność postaci, swoista surrealność), nieistniejącą w żadnej z omawianych słowiańskich edycjii27 (aż do „nowej” Złotej różdżki, której szata graficzna, choć w zupełnie innym stylu, również ma hamować interpretacje „serio”). W sumie - wszystkie wydania „starej” Złotej róźdżki, zarówno w warstwie tekstowej, jak i obrazowej, dążyły nieodmiennie do minimalizacji wieloznaczności charakterystycznej dla oryginału:

Skłonność polskiego tłumacza do dopisywania i pointowania, jak i warstwa ilustra-
cyjna, zarówno z wydań petersburskich, jak i warszawskich, znacznie ograniczyły
możliwość odczytania obecnej u Hoffmanna ambiwalencji. W edycjach Złotej różdźki
trudniej dopatrzeć się przewrotności, czy nawet rewolucyjności, którym nadano
bardziej realistyczny, mniej niepokojący i bardziej dydaktyczny wymiar ${ }^{28}$.

Najciekawszym z naszego punktu widzenia rysem oryginalnych utworów Hoffmanna jest swoisty apsychologizm, dystans narratora do przedsta-

mów do gaimana, Kraków 2016, 330 stron”, Rocznik Przekładoznawczy, nr 13 (2018), DOI: http://dx.doi.org/10.12775/RP.2018.017.

27 Dybiec-Gajer, „Złota różdżka - od książki dla dzieci po dreszczowiec raczej dla dorosłych”: 140-155.

28 Dybiec-Gajer, „Złota różdżka - od książki dla dzieci po dreszczowiec raczej dla dorosłych”: 173. 
wionych zdarzeń, ale także chłód emocjonalny postaci, zwłaszcza postaci dziecięcych - nieczułość wobec otaczającego ich świata, innych ludzi i zwierząt. Uderza w szczególności obojętność bohaterów wobec spadających na nich potwornych kar i nieszczęść:

Charakterystyczną cechą wierszy w zbiorze jest zdystansowanie narratora. To właśnie ambiwalentna postawa narratora, który powstrzymuje się od komentowania zachowań bohaterów, a także postawa protagonistów dziecięcych, którzy mimo kary nie okazują skruchy ani chęci poprawy, przyczyniły się do kontrowersyjności zbioru ${ }^{29}$.

Joanna Dybiec-Gajer zauważa w związku z tym tendencję - obecną nie tylko w pierwszym tłumaczeniu Struwwelpetera, ale także w późniejszych przekładach i adaptacjach, zarówno profesjonalnych, jak i amatorskich (autorka opisuje np. tłumaczenia wykonane przez studentów), a dodatkowo także w słynnym przekładzie Marka Twaina na język angielski - do „dopisywania" Hoffmannowskim bohaterom nieobecnych w oryginale afektów. Zjawisko to nazywa „kompensacją emocjonalną"30.

Przyjrzyjmy się zatem funkcjonowaniu motywu łez w trzech wydanych drukiem tłumaczeniach (ewentualnie adaptacjach, ze względu na opisaną wyżej złożoność sytuacji) Struwwelpetera na język polski ${ }^{31}$.

\section{Łzy źródłowe}

W oryginalnym utworze Hoffmanna pojawia się dwukrotnie czasownik „weinen” (płakać), w różnych formach osobowych, i raz rzeczownik „Träne” (łza), w liczbie mnogiej. Jedno z wystąpień czasownika odnajdziemy w wierszu o złośliwym Friederichu, który znęcał się nad psem i został przez niego ugryziony:

29 Dybiec-Gajer, „Wiersz dla dzieci w przekładzie profesjonalnym i amatorskim - «Der Wilde Jäger» ze zbioru «Struwwelpeter» («Złota różdżka») po polsku”, 249.

30 Dybiec-Gajer, „Wiersz dla dzieci w przekładzie profesjonalnym i amatorskim - «Der Wilde Jäger» ze zbioru «Struwwelpeter» («Złota różdżka») po polsku”, 249-250.

31 Podstawą moich analiz będą następujące edycje: Heinrich Hoffmann, Złota rószczka. Czytajcie dzieci, uczcie się, jak to niegrzecznym bywa źle, w opracowaniu i z posłowiem Janusza Dunina (Łódź: Wydawnictwo Verso, 2003). Jest to reprint czwartego wydania petersburskiego w anonimowym tłumaczeniu (które z dużym prawdopodobieństwem przypisuje się Wacławowi Szymanowskiemu). Dalej oznaczam jako Zr; Heinrich Hoffmann, Piotruś Rozczochraniec. Wesołe historyjki i zabawne rysunki Heinricha Hoffmanna, przeł. Lech Konopiński (Heidelberg: Edition Tintenfass, 2015/2019, wydanie dwujęzyczne). Dalej oznaczam jako LK; Heinrich Hoffmann, Złota różdżka, czyli bajki dla niegrzecznych dzieci, il. Justyna Sokołowska (Warszawa: Egmont Polska, 2017). Adaptacje utworów Hoffmanna: Anna Bańkowska, Karolina Iwaszkiewicz, Zuzanna Naczyńska, Adam Pluszka, Michał Rusinek i Marcin Wróbel. Dalej nZr. 
Der bitterböse Friederich,

Der schrie und weinte bitterlich ${ }^{32}$.

Po raz drugi czasownik „weinen” jest użyty w historyjce o Paulinchen, która spłonęła $\mathrm{w}$ następstwie nieodpowiedzialnej zabawy zapałkami. Dziewczynkę opłakują jej zrozpaczone koty, Minz i Maunz. Rzeczownik „Tränen” występuje w tym samym utworze, spotykając się $\mathrm{z}$ „weinen” $\mathrm{w}$ jednej strofie:

Und Minz und Maunz, die kleinen,

Die sitzen da und weinen:

»Miau! Mio! Miau! Mio!

Wo sind die armen Eltern! Wo?«

Und ihre Tränen fließen

Wie's Bächlein auf den Wiesen.

Mamy więc w istocie u Hoffmanna tylko dwie sceny płaczu: jedna z nich jest zupełnie naturalistyczna - płacze (i krzyczy) pogryziony chłopiec, w niemal fizjologicznej reakcji na ból; druga jest związana z rozbudowaną antropomorfizacją kotów, które pod nieobecność dorosłych wchodzą wobec bohaterki w rolę opiekunów i przyjaciół - bezskutecznie próbują ją ostrzec, a potem płaczą z rozpaczy po jej śmierci.

Sytuacja w polskich wersjach jest bez wyjątku odmienna. We wszystkich trzech wariantach spolszczenia Struwwelpetera motyw łez występuje globalnie w tekście polskim częściej niż w oryginale, a ponadto jest reprezentowany przez większą liczbę leksemów. Odnajdziemy ich łącznie sześć: rzeczowniki „łza” (wyłącznie w liczbie mnogiej) i „płacz” (oba wyrazy wystąpiły we wszystkich tłumaczeniach), czasownik „płakać” (w Zr i nZr); ponadto nacechowane: czasownik „łkać” i rzeczownik „bek” (oba tylko LK) oraz rzeczownik „łkanie” (tylko nZr). Wyrazy powiązane z płaczem pojawiają się w dziewiętnastowiecznym przekładzie Szymanowskiego łącznie siedmiokrotnie (trzykrotnie „płacz”, dwukrotnie „łzy” i dwukrotnie „płakać”), równie licznie, choć w większym zróżnicowaniu leksykalnym, u Lecha Konopińskiego (cztery razy „łzy”, raz „płacz”, „bek” i „łkać), nieco rzadziej w „nowej” Złotej różdżce - w sumie pięć razy (dwukrotnie „łzy”, raz „płacz”, „płakać” i „łkania”).

Przyjrzyjmy się najpierw tłumaczeniom tych fragmentów Struwwelpetera, w których wyrazy związane z motywem łez wystąpiły w oryginale (tab. 1).

32 Cytaty z niemieckiego oryginału według jubileuszowego wydania setnego: Heinrich Hoffmann, Der Struwwelpeter oder Lustige Geschichten und drollige Bilder von Dr. Heinrich Hoffmann, [Frankfurt] 1876, skan dostępny na stronie http://www.gasl.org/refbib/Hoffmann_Struwwelpeter.pdf. 
Tab. 1

\begin{tabular}{|c|c|c|}
\hline Złota różdżka & Piotruś Rozczochraniec & „nowa” Złota różdżka \\
\hline $\begin{array}{l}\text { Krew trysnęła, Józio } \\
\text { w płacz. / Gwałtu! Boli! } \\
{[\ldots]}\end{array}$ & $\begin{array}{l}\text { Krew się lała, chłopiec w bek, } \\
\text { / a pies nań się całkiem } \\
\text { wściekł! / Brzmiał żałośnie } \\
\text { Fryca krzyk [...] }\end{array}$ & [fragment opuszczony] \\
\hline $\begin{array}{l}\text { Miauczek z Mruczkiem już } \\
\text { nie skaczą, / Oni także } \\
\text { Kasi płaczą: / „Gdzie } \\
\text { panienka nasza? miau! / } \\
\text { Gdzie jej biedna mama? } \\
\text { miau?” / I tak płaczą nad } \\
\text { dzieciną, / Że strumieniem } \\
\text { łzy im płyna. }\end{array}$ & $\begin{array}{l}\text { [...] łzy leje kot i kotka łka; / } \\
\text { koteczki dwa maleńkie / } \\
\text { żegnają swą panienkę: } \\
\text { „Miau! Mijo! Kto to wie, / Gdzie } \\
\text { są rodzice? Gdzie? / I potok łez } \\
\text { znów płynie / Jak strumyk po } \\
\text { dolinie. }\end{array}$ & $\begin{array}{l}\text { Obok poczciwe kotki siedziały, } \\
\text { / a z oczu ciurkiem tzy im się } \\
\text { lały. / - Miauuu... Co poczniemy } \\
\text { bez naszej Hani? / - Miauuu... } \\
\text { co powiemy mamie i niani? / } \\
\text { Z tych łez serdecznych Puszka } \\
\text { i Duszka / wnet się zrobiła } \\
\text { słona kałużka. }\end{array}$ \\
\hline
\end{tabular}

Godną uwagi różnicą jest brak opisu reakcji pogryzionego Szymka (bo takie imię nosi w „nowej” Złotej różdżce odpowiednik złego Friedericha) tym samym jedna $\mathrm{z}$ dwóch scen płaczu w utworze Hoffmanna nie znalazła żadnego odzwierciedlenia w trzeciej wersji polskiej. Karolina Iwaszkiewicz zdecydowała się natomiast na znaczne rozbudowanie opisu zachowania zdesperowanego psa. Po scenie ugryzienia pojawia się coś na kształt filmowego cięcia:

Suka piszczy, skomli, wyje...
Nagle - łapie rękę z kijem!
Wbija zęby aż do kości,
zwiera szczęki bez litości,
szarpie, targa i dociska,
gęstą pianę tocząc z pyska.
Leży Szymek na kanapie,
Krew z obrzmiałej rany kapie.
Doktor zastrzyk już szykuje,
Zaraz Szymka w brzuch ukłuje.

O złym Szymku, 30-32

Ten charakterystyczny brak motywu łez powoduje, jak sądzę, idące jeszcze dalej niż w oryginale „odczłowieczenie” postaci sadystycznego chłopca. Fabuła opowieści o złym Friederichu jest zresztą niezwykle wieloznaczna jest to, moim zdaniem, jedyny w zbiorku Hoffmanna wiersz całkowicie powstrzymujący identyfikację dziecięcego czytelnika z bohaterem dziecięcym. Postacią uruchamiającą mechanizmy projekcji i identyfikacji jest natomiast maltretowany pies, z pozoru słabszy, podporządkowany człowiekowi i bezbronny, nieoczekiwanie zyskujący możliwość ukarania swojego bezwzględnego dręczyciela. Wraz z rozwojem akcji postępuje także antropomorfizacja 
zwierzęcia, może wręcz transfiguracja: zasiadając przy stole Friedericha, by delektować się odebranym mu posiłkiem, pies staje się figurą poniżanego człowieka, być może samego dziecka, które zdobyło zastrzeżone dotąd dla dorosłych prawa. Nieoczekiwana finałowa scenka o cechach fantazji kompensacyjnej (pies konfiskuje bat, którym był bity, i spożywa obiad przygotowany dla swojego oprawcy, chorego teraz i skazanego na gorzkie lekarstwa) jest echem tradycyjnej konwencji świata-na-opak, a także domknięciem szeregu paralelizmów, podwojeń i powtórzeń, kluczowych dla symetrycznej kompozycji, w której zresztą niebagatelną rolę odgrywa motyw płaczu. Pełen zwierciadlanych odbić jest opis agresji chłopca i cierpienia psa oraz następującej jako konsekwencja agresji psa i cierpienia chłopca, którego krzyk i płacz (,...Der schrie und weinte bitterlich”) był poprzedzony wyciem psa („Und schlug den Hund, der heulte sehr”). Paralelizm jest także widoczny na poziomie wyborów leksykalnych: dwukrotnie użyte w odniesieniu do Friedericha dręczącego psa określenie „bitterböse” odpowiada parzystym wyrazom opisującym późniejsze bolesne doświadczenia chłopca: „bitterlich” i „bittre” („Herr Doktor gibt ihm bittre Arzenai”). Przypisywany tej opowiastce zamiar moralizatorski wydaje mi się pozorny - w moim przekonaniu niesie ona przede wszystkim kojący obraz sprawiedliwej kary za okrucieństwo, dzięki czemu mogła być źródłem pociechy dla dzieci doświadczających przemocy lub cierpiących z powodu poczucia bezsilności wobec wszechwładzy dorosłych ${ }^{33}$.

Zasadniczo scena płaczu, który jest znakiem symetrycznego odwrócenia relacji postaci, ma w przekładach Szymanowskiego i Konopińskiego zbliżony do oryginału sens, mimo odmiennych wyborów leksykalnych i kompozycyjnych, wyrażających się zwłaszcza w mnożeniu określeń płaczu. W wersji Konopińskiego uwagę zwraca amplifikacja: kolokwialne określenie „Józio w bek", pogłębiające upokorzenie pokonanego sprawcy przemocy (co więcej, jego krzyk jest „żałosny”). Brak motywu płaczu w wersji z „nowej” Złotej

33 W psychoanalitycznej interpretacji Anity Eckstaedt pies jest symbolicznie sumieniem karzącym Friedericha: Heinrich Hoffmann, który doświadczył w dzieciństwie dramatu śmierci matki, odebrał wychowanie zachęcające do tłumienia emocji i wypierania traumatycznych przeżyć, zatem nie odbył nigdy żałoby i nie pogodził się ze stratą. Dlatego gniew i złość Friedericha (figury autora jako dziecka, które odczuwa żal i wściekłość, nie mogąc zaakceptować swojego losu i świata) zostają natychmiast stłumione za sprawą „ukąszenia psa" - to ingerencja wewnętrznego sędziego, który nakazuje dziecku spokój. Bunt i cierpienie, wypchnięte poza świadomość, przyjmują formę somatyzacji: gwałtownej gorączki, w efekcie której Friederich staje się ciężko chory. W tej interpretacji historia Friedericha jest także dokumentem głębokiego, nieświadomego poczucia winy: to dziecko sądzi, że jest bardzo złe, skoro matka je porzuciła. Por. Anita Eckstaedt, „Der Struwwelpeter”. Dichtung und Deutung. Eine psychoanalytische Studie (Frankfurt am Main: Suhrkamp Verlag, 1998), 45-58 i 167. 
różdżki wydobywa, moim zdaniem, na pierwszy plan zwierzę i problem jego uzależnienia od człowieka; figuratywny sens historii ulega chyba osłabieniu.

Jeśli chodzi o drugi utwór Hoffmanna z motywem łez, Die gar traurige Geschichte mit dem Feuerzug, interesujący nas fragment pojawia się we wszystkich bez wyjątku wersjach polskich. Scena z płaczącymi kotami ma $\mathrm{w}$ oryginale przejrzystą strukturę, którą powtarzają wszystkie tłumaczenia, tym bardziej że znajduje ona dodatkowe wsparcie w warstwie ikonograficznej: koty siedzą w hieratycznych pozach nad kupką dymiącego jeszcze popiołu, który pozostał ze spalonej dziewczynki, a łzy, płynące z ich oczu, formują dwa strumyczki, opływające doczesne szczątki Paulinchen oraz śliczne czerwone buciki, wspomniane w przedostatniej strofie. Pantofelki z niewyjaśnionych powodów nie spłonęły i stanowią ostatnią pamiątkę po zbuntowanej dziewczynce z zapałkami (nota bene zarówno Dziewczynka z zapałkami, jak i Czerwone trzewiki Andersena ukazały się, podobnie jak pierwsze wydanie Struwwelpetera, w roku 1845). Koty noszą na ogonach żałobne czarne kokardy, a w łapkach trzymają eleganckie chusteczki, które przyciskają do oczu i nosków. Całość, łącząca podniosły nastrój pompy pogrzebowej, sentymentalną antropomorfizację i hiperboliczny obraz „rzeki łez”, jest w oczywisty sposób groteskowa. W podobnej estetyce utrzymany jest tekst Hoffmanna: celebrowana przez koty ceremonia żałobna obejmuje kontemplację szczątków, pełne żalu pytania retoryczne, nawiązujące do toposu „ubi sunt..." (choć warto podkreślić, że w oryginale koty zastanawiają się tylko, gdzie są rodzice zwęglonego dziecka, a nie ono samo), oraz opis łez, płynących jak strumień. Tłumaczenia są na ogół wierne - tylko Szymanowski dodaje od siebie pytanie o miejsce pobytu zmarłej Kasi (pytania tego nie ma też w tekście rosyjskim, z którego najprawdopodobniej tłumaczył), a Anna Bańkowska, tłumaczka Strasznej historii o Hani i zapałkach w „nowej” Złotej różdżce, zupełnie rezygnuje z pytania "gdzie”, przypisując w zamian kotom poczucie odpowiedzialności za tragedię, do której doszło, a także strach przed reakcją dorosłych (z pewnością można uznać tę innowację za najdalej idące przekształcenie intencji oryginału). We wszystkich bez wyjątku wersjach groteskowy aspekt kocich łez zostaje, moim zdaniem, zachowany w tłumaczeniu, dzięki czemu motyw płaczu pozwala rozbroić straszną scenę samospalenia. Polszczyzna, dysponująca idiomem "tyle, co kot napłakał”, jest tu chyba szczególnie predysponowana do generowania efektów komicznych.

\section{Nadwyżka łez}

Pozostałe przykłady motywu łez w polskich wersjach Struwwelpetera są bez wyjątku dodatkami tłumaczy. Ich rozkład przedstawia tab. 2 . 
Tab. 2

\begin{tabular}{|c|c|c|c|}
\hline & Złota różdżka & Piotruś Rozczochraniec & „nowa” Złota różdżka \\
\hline \multirow[t]{2}{*}{ Łzy } & \multirow{2}{*}{$\begin{array}{l}\text { Przygoda złego Józia } \\
\text { (motyw łez po raz drugi) } \\
\text { Bez przyczyny dręczyć - } \\
\text { grzech; / Piesek zawył! - } \\
\text { Józio w śmiech, / lecz po } \\
\text { śmiechu często łzy [...] }\end{array}$} & $\begin{array}{l}\text { Dzieje czarnych chłopców } \\
\text { Po co wyciskać chłopcu łzy, / że } \\
\text { nie jest biały tak jak wy? }\end{array}$ & \\
\hline & & $\begin{array}{l}\text { Janek Nos-wśród-chmur } \\
\text { Tylko rybki - wszystkie trzy - / } \\
\text { wystawiły z wody łby; / Jankiem } \\
\text { wstrząsa zimny dreszcz; / one } \\
\text { śmieją się do łez! }\end{array}$ & \\
\hline Płacz & $\begin{array}{l}\text { Czarne dzieci } \\
\text { Aż psotniki w jednej chwili } \\
\text { / Atramentu się napili. / } \\
\text { Toż tam było płaczu, } \\
\text { wrzasku. }\end{array}$ & $\begin{array}{l}\text { Dzieje palcossacza } \\
\text { Odciął dziecku kciuki drab. / Nic } \\
\text { nie pomógł płacz i krzyk, / Bo za } \\
\text { drzwiami krawiec znikł. }\end{array}$ & $\begin{array}{l}\text { O Konradzie, co } \\
\text { obgryzał paznokcie } \\
\text { Rach-ciach! I prawej } \\
\text { nie ma już ręki! / } \\
\text { Rach-ciach! I lewej! } \\
\text { Płacz! Krzyk! I jęki. } \\
\end{array}$ \\
\hline Płakać & $\begin{array}{l}\text { O Juleczku, co miał zwyczaj } \\
\text { ssać palec } \\
\text { Płacze Julek, żal niebodze, } \\
\text { / A paluszki na podłodze. }\end{array}$ & & $\begin{array}{l}\text { O Konradzie, co } \\
\text { obgryzał paznokcie } \\
\text { Mama wróciła, } \\
\text { a Konrad płacze. }\end{array}$ \\
\hline Łkania & & & $\begin{array}{l}\text { O latajacym Robercie } \\
\text { Nikt nie słyszy łkań } \\
\text { i wycia, / wkrótce jest } \\
\text { jak kropka tycia... }\end{array}$ \\
\hline
\end{tabular}

Można zauważyć, że jedna z opowiastek Hoffmanna, Die Geschichte vom Daumenlutscher, po polsku występująca pod trzema tytułami: $O$ Juleczku, co miał zwyczaj ssać palec (Zr), Dzieje palcossacza (LK) oraz O Konradzie, co obgryzał paznokcie (nZr), jest faworytką zestawienia - każdy z trzech tłumaczy zdecydował się na wprowadzenie do niej motywu łez, czasem w jednym miejscu (Szymanowski i Konopiński), czasem w dwóch (Marcin Wróbel w „nowej” Złotej różdżce) $)^{34}$ - tab. 3.

Można zauważyć, że każdy z trzech tłumaczy wprowadza motyw płaczu albo by oddać czasownik „schreien”, albo przymiotnik „traurig”, albo w obu kontekstach. Jest to z pewnością opisywana przez Joannę Dybiec-Gajer kompensacja emocjonalna, wynikająca z (niekoniecznie uświadomionej) potrzeby zintensyfikowania afektów dziwnie opanowanych bohaterów wierszy Hoffmanna. W przypadku Wacława Szymanowskiego bezpośrednim źró-

34 Odpowiedni fragment oryginału: „[...] Jetz geht es klipp und klapp / Mit der Scher’ die Daumen ab, / Mit der großen scharfen Scher'! / Hei! Da schreit der Konrad sehr. Als die Mutter kommt nach Haus, / Sieht der Konrad traurig aus. / Ohne Daumen steht er dort, / Die sind alle beide fort". 
dłem był prawdopodobnie tekst rosyjski, w którym także występuje motyw łez. Lech Konopiński, na ogół wiernie podążający za oryginałem, tym razem łagodzi obraz dorosłych, przypisując uczucie żalu nie Konradowi, lecz jego mamie - u Hoffmanna obojętnej, u Szymanowskiego dość okrutnej, by zaaplikować pozbawionemu kciuków chłopcu kolejną karę: odebranie ciastek ${ }^{35}$. Dydaktyczne nastawienie mamy powraca - być może jako echo „starej” Złotej różdżki - w groteskowej i ponad wszelką miarę krwawej adaptacji Marcina Wróbla. Myślę, że niezależnie od wszelkich różnic między poszczególnymi przekładami motyw łez odgrywa w nich doraźnie identyczną rolę: jest nią intensyfikacja emocji postaci, a tym samym - czytelnika. Nadrzędne cele bywają jednak różne: może chodzić o wychowawcze nasilenie strachu (Zr), wzbudzenie współczucia dla postaci dziecięcej (LK), wyolbrzymienie sygnalizujące konwencję grozy (nZr), przy czym zabiegi te bywają wpisane w tekst niekoherentnie, skłaniając czytelnika, by nie brał katastrofy Konrada całkiem serio (LK, NZr).

Tab. 3

\begin{tabular}{|c|c|c|}
\hline Złota różdżka & Piotruś Rozczochraniec & „nowa” Złota różdżka \\
\hline $\begin{array}{l}\text { Uciął palec jeden, drugi / Aż } \\
\text { krew prysła we dwie strugi, } \\
\text { Julek w krzyk, a krawiec } \\
\text { rzecze: / „Tak } \\
\text { z nieposłuszeństwa leczę!” }\end{array}$ & \begin{tabular}{|l|} 
Teraz szybkie „klip” \\
i „klap”; / Odciął dziecku \\
kciuki drab. / Nic nie \\
pomógł płacz i krzyk, / Bo \\
za drzwiami krawiec znikł.
\end{tabular} & $\begin{array}{l}\text { Rach-ciach! I prawej nie ma } \\
\text { już ręki! / Rach-ciach! I lewej! } \\
\text { Płacz! Krzyk! I jęki. }\end{array}$ \\
\hline $\begin{array}{l}\text { Wraca mama, aj! wstyd! bieda! / } \\
\text { Juleczkowi ciastek nie da, / Bo } \\
\text { kto mamy nie usłucha, / Temu } \\
\text { dosyć bułka sucha. } \\
\text { Płacze Julek, żal niebodze, / } \\
\text { A paluszki na podłodze. }\end{array}$ & $\begin{array}{l}\text { Gdy bez palców malec stał, } \\
\text { / W oczach mamy ujrzał } \\
\text { żal: / Nie ma Konrad } \\
\text { kciuków już! / Cóż więc } \\
\text { będzie pchał do ust?! }\end{array}$ & $\begin{array}{l}\text { Mama wróciła, a Konrad } \\
\text { płacze. / - Chodź no tu synku, } \\
\text { niech no zobaczę, / czy } \\
\text { grzeczny byłeś, czy } \\
\text { posłuchałeś, / czy też } \\
\text { paznokcie znów obgryzałeś? }\end{array}$ \\
\hline
\end{tabular}

W pozostałych pięciu przypadkach introdukcji interesującego nas motywu rzecz ma się zupełnie inaczej - każdy z tłumaczy wprowadza łzy w innym miejscu.

\section{Złota różdżka i płacz w finale}

Zarówno Szymanowski, jak i Konopiński umieszczają motyw łez w opowieści o dzieciach, które bezdusznie drwiły z czarnoskórego spacerowicza

35 Por. Dybiec-Gajer, „Złota różdżka - od książki dla dzieci po dreszczowiec raczej dla dorosłych", 145-148. 
i zostały za karę zanurzone w atramencie przez Niklasa - świętego Mikołaja (w wersji dziewiętnastowiecznej nazwanego starym czarodziejem). Zbieżność jest jednak pozorna, ponieważ motyw płaczu występuje w dwóch zupełnie różnych kontekstach. Zacznijmy od Złotej różdżki, w której łzy pojawiają się na końcu: płaczą mali złoczyńcy przytapiani w kałamarzu. Zaatakowany przez nich czarnoskóry, zdaniem pozostałych tłumaczy, sam także jest dzieckiem, natomiast u Szymanowskiego pojawia się określenie „czarny pan", sugerujące, że chodzi o młodego dorosłego. Ogólna sytuacja przedstawiona w utworze rysuje się więc zupełnie inaczej - w Złotej różdżce do problemu nietolerancji rasowej dodano jeszcze element konfliktu pokoleń: nie chodzi już o antagonizmy w środowisku dzieci, lecz o atak dzieci na dorosłego.

W Czarnych dzieciach obserwujemy narastającą intensyfikację strachu, cierpienia i upokorzenia nieznośnych bohaterów. Opowieść w wersji Szymanowskiego jest $\mathrm{w}$ istotny sposób rozbudowana: utwór liczy 50 wersów (39 w oryginale, $40 \mathrm{w}$ wersji rosyjskiej), co wiąże się głównie z dodaniem całego szeregu pouczających wypowiedzi: czarodzieja, stworzonej ad hoc postaci wyśmiewającego chłopców kruka, i narratora, który podsumowuje opowieść morałem: „Tak się wszystkim malcom stanie za niesłuszne wyśmiewanie!”. Łzy, o czym była już mowa, także pojawiają się w finale:

\footnotetext{
„Tego nadto - krzyknął stary.

Nieposłusznym trzeba kary!"

Chwyta wszystkich trzech za włosy

I choć krzyczą wniebogłosy,

Olbrzym na to nie uważa,

Wszystkich buch! do kałamarza.

Aż psotniki w jednej chwili

Atramentu się napili.

Toż tam było płaczu, wrzasku.

Teraz patrzcie na obrazku $[\ldots]^{36}$.
}

Moralizatorska wypowiedź czarodzieja („trzeba kary!”) nie jest jedynym przejawem nasilonego dydaktyzmu - warto zauważyć, że w oryginale chłopcy nie tylko nie płaczą, ale także opierają się przemocy, a Kaspar daje nawet dowód przytomności umysłu, wołając: „pali się!”. Drobne akcenty humorystyczne i odwaga nieznośnych dzieci nie zdały widać egzaminu z dydaktyzmu w oczach tłumacza, który wprowadził w zamian motyw płaczu na znak ich upokorzenia. Zmiany te nie znajdują też wzorca w rosyjskiej Stiopce-rastriopce.

36 Odpowiedni fragment oryginału: „Der Niklas wurde bös und wild, / Du siehst es hier auf diesem Bild! / Er packte gleich die Buben fest, / Beim Arm, beim Kopf, bei Rock und West', / Den Wilhelm und den Ludewig, / Den Kaspar auch, der wehrte sich. / Er tunkt sie in die Tinte tief, / Wie auch der Kaspar: «Feuer!» rief. / Bis übern Kopf ins Tintenfaß / Tunkt sie der große Nikolas". 
Odnajdziemy natomiast przykłady finałowego płaczu w polskiej poezji dydaktycznej połowy XIX wieku. Struuwelpeter jako Złota różdżka został przyswojony polszczyźnie na wczesnym etapie rozwoju rodzimej literatury dla dzieci, krótko po śmierci obojga jej pionierów: Klementyny z Tańskich Hoffmanowej i Stanisława Jachowicza, którego dydaktyczna twórczość jest, jak sądzę, najważniejszym polskim kontekstem dla przekładu Szymanowskiego. Moralizatorska mieszczańska poezja autora Bajek i powieści (1824), Powiastek i bajek (1842) czy Śpiewów dla dzieci (1857) miała w wieku XIX niezmiernie żywą recepcję ${ }^{37}$, zresztą do dziś jeszcze pojedyncze utwory Jachowicza (zwłaszcza Chory kotek) są wznawiane i czytane przez dzieci. Fabularny schemat wielu utworów przypomina słynną historyjkę Andzi: nieposłuszne dziecko robi sobie krzywdę i płacze:

Nie rusz, Andziu, tego kwiatka;

Róża kole, rzekła Matka.

Andzia Mamy nie słuchała,

Ukłuła się i płakała.

Płacz, zawstydzenie, upokorzenie, nieuchronny żal, towarzyszący zasłużonym cierpieniom, to w wierszykach Jachowicza ostateczny obraz przegranej dziecka i podwójnej kary, w której fizyczne cierpienie splata się z poniżeniem. Płacz jest zatem zawsze „po”, negatywne emocje są zwieńczeniem dydaktycznego dzieła. Choć nie znajdujemy tej tendencji u Heinricha Hoffmana, w przekładzie Szymanowskiego jest ona równie częsta, jak u Jachowicza.

Wyrazem tej samej strategii jest też ostatni przykład dodania motywu łez w Złotej różdżce - chodzi o Przygodę złego Józia, utwór, w którym, jak pamiętamy, Heinrich Hoffmann kazał zapłakać z bólu pogryzionemu Friederichowi - sadyście. Szymanowski dodaje jednak pouczający i profetyczny komentarz w poprzedniej strofie, gdzie Józio śmieje się z wycia cierpiącego psa: „Lecz po śmiechu często łzy”.

\section{Piotruś Rozczochraniec i łzy niewinnych}

Również u Konopińskiego łzy pojawiły się w opowiastce o trzech małych łobuzach, zabawiających się rasistowskimi drwinami z przechodnia. Utwór nosi w tej wersji tytuł Dzieje czarnych chłopców, a motyw płaczu został wprowadzony w zupełnie innym miejscu: Mikołaj apeluje do złośliwych malców, by zaniechali żartów, które ranią uczucia czarnoskórego chłopca i mogą go skłonić do płaczu.

37 Izabela Kaniowska-Lewańska, Literatura dla dzieci i młodzieży do roku 1864 (Warszawa: Wydawnictwa Szkolne i Pedagogiczne, 1980), 77-85. 
Po co wyciskać chłopcu łzy,

że nie jest biały tak jak wy? ${ }^{38}$

Co warto zauważyć, Lech Konopiński akcentuje fakt, że zaatakowany także jest dzieckiem (istotnie przemawiają za tym użyte przez Hoffmanna wyrazy „Mohrchen” i „Mohrenkind”). Wymowa utworu Dzieje czarnych chłopców Konopińskiego jest na ogół bardzo bliska sensom oryginału, ale drobna różnica w zacytowanym dwuwierszu akcentuje odmienną argumentację: rzecz nie w tym, że czarnoskóry chłopiec nie ma wpływu na swój los, chodzi raczej o to, że ofiara napaści jest wrażliwym człowiekiem, należy chronić jej uczucia. Motyw łez w przekładzie Konopińskiego (podobnie jak smutek mamy w jego tłumaczeniu historyjki o Konradzie „palcossaczu”) poszerza spektrum emocji postaci drugoplanowych.

W Piotrusiu Rozczochrańcu obserwujemy jeszcze jeden, oryginalny w zestawieniu z pozostałymi przekładami, dodatek - motyw łez został wprowadzony jako element związku frazeologicznego „śmiać się do łez”. Łzy stają się w tym utartym zwrocie miarą szczerego śmiechu, przywołane jako somatyczny przejaw wesołości. Amplifikacja Konopińskiego wpisuje się w estetykę świata-na-opak, który po raz kolejny pojawia się na chwilę w wierszu Janek Nos-wśród-chmur (Die Geschichte vom Hans Guck-in-die-Luft): ryby śmieją się z człowieka, który przez nieuwagę wpadł do wody i omal nie przypłacił tego życiem.

\section{„Nowa” Złota różdżka i rozpaczliwe łkania}

Ze względu na duże zróżnicowanie, trudno wypowiadać się ogólnie o „nowej” Złotej róźdżce; pewne widoczne w niej tendencje obecne są tylko w niektórych utworach. Tu chciałabym zwrócić uwagę na dwa wierszyki, jedyne, w których motyw łez został wprowadzony decyzją tłumaczy. Jest to omówiona już historyjka $O$ Konradzie, który obgryzał paznokcie oraz ostatni przykład motywu łez: umieszczony w ostatniej historyjce zbiorku, O latajacym Robercie.

Niezwykła opowieść o chłopcu, który nieostrożnie wyszedł z domu mimo nawałnicy, został porwany przez wiatr i przepadł bez wieści, przykuwała uwagę czytelników ${ }^{39}$ i okazała się podatna na interpretacje symboliczne: psychoanalityczka Anita Eckstaedt czyta tę historyjkę jako element nieświadomie ujawnionej w utworze intymnej autobiografii Hoffmanna,

38 W oryginale: „Was kann denn dieser Mohr dafür, / Daß er so weiß nicht ist wie ihr?”.

39 Por. wspomnienia Haliny Micińskiej-Kenarowej, przytaczane przez Joannę Dybiec-Gajer, „Złota różdżka - od książki dla dzieci po dreszczowiec raczej dla dorosłych”, 131-132. 
osieroconego we wczesnym dzieciństwie przez matkę, do której chłopiec pragnął uciec, fantazjując o podróży do nieba ${ }^{40}$.

Tłumacz Adam Pluszka zdecydował się na sformułowanie: „Nikt nie słyszy łkań i wycia, / wkrótce jest jak kropka tycia...", tłumacząc dwa wersy Hoffmana: „Niemand hört ihn, wenn er schreit. / An die Wolken stößt er schon [...]". Jest to więc kolejna sytuacja, w której polski tłumacz sięga po wyraz „płakać” lub synonim, by oddać niemiecki leksem „schreien”. Tu dodatkowo, prócz „łkań”, pojawia się jeszcze „wycie”, reakcja porwanego przez wiatr Roberta ulega więc daleko idącej hiperbolizacji. Strategia ta, choć pozornie mogłaby się kojarzyć z amplifikacjami Szymanowskiego, ma, jak sądzę, zupełnie inny cel: jest nim widoczne także w innych wierszach „nowej” Złotej różdżki nasilenie makabry, okropności i grozy, zbliżające utwór czasem do horroru, czasem do groteski. Konwencje te, w ostatnich dekadach święcące tryumfy w polskiej i światowej kulturze dziecięcej, są dobrze już znane małym czytelnikom i otwierają tekst na lekturę ludyczną. „Nowa” Złota różdżka, niezależnie od związków ze swoją „starą” poprzedniczką, wpisuje się przede wszystkim w aktualnie obowiązujące standardy awangardowej książki obrazkowej oraz „buntowniczy” nurt, popularny dziś w polskiej literaturze dziecięcej (mam tu na myśli wyłącznie analizowane wyżej utwory).

Warto na zakończenie odnotować fakt, że motyw łez okazał się swoistym detektorem globalnych strategii: łzy w „starej” Złotej róźdżce pojawiają się w celach dydaktycznych, w „nowej” - by zintensyfikować efekt grozy i za sprawą hiperbolizacji osłabić tendencję do lektury „serio”. W tłumaczeniu Lecha Konopińskiego, którego zamierzeniem nie było stosowanie adaptujących przekształceń ${ }^{41}$, łzy pojawiają się w kontekstach neutralnych (jak związek frazeologiczny „śmiać się do łez”), a jeśli prowadzą do dyskretnej zmiany sensu oryginału, są to decyzje podkreślające wrażliwość postaci i nakierowane na budzenie w czytelnikach nie strachu, lecz empatii.

40 Por. Eckstaedt, „Der Struwwelpeter”. Dichtung und Deutung. Eine psychoanalytische Studie, 140-146, 171-172, 184-186.

41 Jak pisze Eliza Pieciul-Karmińska, Piotruś Rozczochraniec jest przekładem, „który stara się odtworzyć pierwotny zamiar artystyczny oryginału (także z racji niezmienionej warstwy graficznej). [...] Dzięki temu wydaniu czytelnik ma szansę lepiej poznać kulturę wyjściową oraz doświadczyć estetycznej wartości dzieła oryginalnego”. Pieciul-Karmińska, „O niektórych aspektach tradycji czytania i przekładania literatury dla dzieci. Na kanwie recenzji książki Joanny Dybiec-Gajer „Złota różdżka - od książki dla dzieci po dreszczowiec raczej dla dorosłych", 395. 


\section{References}

\section{Primary sources}

Hoffmann, Heinrich. Der Struwwelpeter oder Lustige Geschichten und drollige Bilder von Dr. Heinrich Hoffmann. Frankfurt 1876. http://www.gasl.org/ refbib/Hoffmann_Struwwelpeter.pdf.

Hoffmann, Heinrich. Piotruś Rozczochraniec. Wesołe historyjki i zabawne rysunki Heinricha Hoffmanna. Translated by Lech Konopiński. Heidelberg: Edition Tintenfass, 2015/2019.

[Hoffmann, Heinrich]. Złota rószczka. Translated by Waclaw Szymanowski. Warszawa: Graf_ika Usługi Wydawnicze, 2018 [reprint of the third edition, Petersburg: Tow. M.C. Wolff, 1892].

Hoffmann, Heinrich. Złota rószczka. Czytajcie dzieci, uczcie się, jak to niegrzecznym bywa źle, edited and afterword by Janusz Dunin. Łódź: Verso, 2003 [reprint of the fourth edition Petersburg: Tow. M.C. Wolff, 1883].

Hoffmann, Heinrich. Złota różdżka, czyli bajki dla niegrzecznych dzieci, illustrated by Justyna Sokołowska, adapted by Anna Bańkowska, Karolina Iwaszkiewicz, Zuzanna Naczyńska, Adam Pluszka, Marcin Wróbel, and Michał Rusinek. Warszawa: Egmont Polska, 2017.

\section{Secondary sources}

Cackowska, Małgorzata. “O starej 'Złotej rószczce’ i nowej 'Złotej różdżce, czyli bajkach dla niegrzecznych dzieci.'” Kultura Liberalna, no. 35 (451) (2017). https://kulturaliberalna.pl/2017/08/29/malgorzata-cackowska-o-zlotej-rozdzce-kl-dzieciom/.

Cercenac-Lecomte, Constanze. "Der Struwwelpeter." In Deutsche Erinnerungsorte, vol. 3, edited by Etienne François, and Hagen Schulze. München: Verlag C.H. Beck, 2001.

Cieślikowski, Jerzy. "Wstęp." In Antologia poezji dziecięcej, edited by Jerzy Cieślikowski, XLIX-L. Wrocław: Zakład Narodowy imienia Ossolińskich, 1981.

Dunin, Janusz. "Struwwelpeter, Stepka-Rastrepka czyli Złota Różdżka. Z dziejów kariery jednej książki." In Hoffmann, Heinrich. Złota rószczka, 5-28. Łódź: Verso, 2003 [reprint of the fourth edition, Petersburg: Tow. M.C. Wolff, 1883].

Dybiec-Gajer, Joanna. "Implikacje utożsamiania przekładu z oryginałem. Polemika z interpretacją złotej różdżki w książce katarzyny slany groza w literaturze dziecięcej. Od grimmów do gaimana, Kraków 2016, 330 stron." Rocznik Przekładoznawczy, no. 13 (2018): 287-296. DOI: http://dx.doi.org/10.12775/RP.2018.017. 
Dybiec-Gajer, Joanna. "Lokalizacja a przekład dla dzieci: jak utwory strasznieją i mądrzeją w tłumaczeniu na przykładzie 'Stasia Straszydło' i 'Mądrej Myszy'”. In Między tekstem a kulturq̨. Z zagadnień przekładoznawstwa, edited by Aleksandra R. Knapik, and Piotr P. Chruszczewski, 323345. San Diego: Æ Academic Publishing, 2018.

Dybiec-Gajer, Joanna. "Wiersz dla dzieci w przekładzie profesjonalnym i amatorskim - 'Der Wilde Jäger' ze zbioru 'Struwwelpeter' ('Złota różdżka') po polsku." Orbis Linguarum, no. 48 (2018): 235-256.

Dybiec-Gajer, Joanna. Złota różdżka - od książki dla dzieci po dreszczowiec raczej dla dorosłych. Kraków: Tertium, 2017.

Eckstaedt, Anita. "Der Struwwelpeter". Dichtung und Deutung. Eine psychoanalytische Studie. Frankfurt am Main: Suhrkamp Verlag, 1998.

Flitner, Andreas. Konrad, sprach die Frau Mama... Über Erziehung and NichtErziehung. Weinheim/Basel: Beltz Taschenbuch, 2009.

Jonca, Magdalena. "Historie o Stasiu Straszydle i innych rozrabiakach (Heinrich Hoffmann: 'Złota różdżka')." In Arcydzieła literatury niemieckojęzycznej. Szkice, komentarze, interpretacje, vol. 2, edited by Edward Białek, and Grzegorz Kowal, 9-20. Wrocław: Oficyna Wydawnicza Atut, 2011.

Kaniowska-Lewańska, Izabela. Literatura dla dzieci i młodzieży do roku 1864. Warszawa: Wydawnictwa Szkolne i Pedagogiczne, 1980.

Leszczyński, Grzegorz. Ksiq̨żki pierwsze. Ksiq̨żki ostatnie? Literatura dla dzieci i młodzieży wobec wyzwań nowoczesności. Warszawa: Wydawnictwo Stowarzyszenia Bibliotekarzy Polskich, 2012.

Pieciul-Karmińska, Eliza. "O niektórych aspektach tradycji czytania i przekładania literatury dla dzieci. Na kanwie recenzji książki Joanny DybiecGajer 'Złota różdżka - od książki dla dzieci po dreszczowiec raczej dla dorosłych."' Porównania, no. 1 (2018): 287-296, DOI: http://dx.doi.org/ 10.14746/por.2018.1.22.

Pieciul-Karmińska, Eliza. "Polska seria przekładowa 'Dziadka do orzechów i króla myszy’ E.T.A. Hoffmanna.” Studia Interkulturowe, no. 8 (2015): 57-87.

Rusinek, Michał. “Wstęp.” In Heinrich, Hoffmann. Złota różdżka czyli bajki dla niegrzecznych dzieci, illustrated by Justyna Sokołowska, adapted by Anna Bańkowska, Karolina Iwaszkiewicz, Zuzanna Naczyńska, Adam Pluszka, Marcin Wróbel, and Michał Rusinek. Warszawa: Egmont Polska, 2017.

Slany, Katarzyna. Groza w literaturze dziecięcej. Od Grimmów do Gaimana. Kraków: Wydawnictwo Naukowe Uniwersytetu Pedagogicznego, 2016.

Stahl, John Daniel. "Mark Twain's 'Slovenly Peter' in the Context of Twain and German Culture." In The Translation of Children's Literature: A Reader, edited by Gillian Lethey, 211-224. Clevedon: Multilingual Matters, 2006. 
Tuwim, Julian. “Michaś i zupa.” In Tuwim, Julian. Cicer cum caule, czyli groch z kapusta, 357-360. Warszawa: Iskry, 2009.

\title{
Gorzkie łzy nieznośnych dzieci w wersji polskiej, czyli o motywie płaczu w tłumaczeniach zbiorku Struwwelpeter Heinricha Hoffmanna
}

\begin{abstract}
Abstrakt: Artykuł jest analizą porównawczą motywu łez w trzech tłumaczeniach utworu Heinricha Hoffmanna Struwwelpeter na język polski. Celem była interpretacja zgromadzonych danych (wskazujących, że wyrazy związane z motywem łez występują we wszystkich przekładach zdecydowanie częściej niż w oryginale) i powiązanie ich z opisanymi w badaniach wcześniejszych, zwłaszcza w pracach Joanny Dybiec-Gajer, strategiami polskich tłumaczy utworu. Ich wybory leksykalne i składniowe oraz zastosowane amplifikacje i przekształcenia wskazują na ścisłe powiązanie kontekstów, w których pojawia się motyw łez, z ogólnymi cechami danego przekładu/adaptacji, w szczególności z tendencją do akcentowania funkcji dydaktycznej lub ludycznej, a z drugiej strony - z projektowanymi reakcjami czytelnika dziecięcego: od strachu, poprzez empatię - do lektury „z przymrużeniem oka”. W artykule zostały także skrótowo zaprezentowane dzieje zbioru Struwwelpeter w Polsce w ciągu 160 lat od pierwszego, anonimowego wydania książki pod tytułem Złota różdżka, a także najważniejsze wątki polskich badań nad utworem. Zasygnalizowano także funkcjonujące w literaturze przedmiotu i krytyce literackiej w Polsce interpretacje Struwwelpetera i Złotej różdżki oraz opisywany w tym kontekście problem utożsamienia przekładu (będącego w istocie adaptacją) z oryginałem.
\end{abstract}

Słowa kluczowe: Struwwelpeter, Złota różdżka, tłumaczenie, adaptacja, funkcja ludyczna, dydaktyzm, empatia.

\section{Bittere Tränen unerträglicher Kinder in der polnischen Fassung. Über das Motiv des Weinens in den Übersetzungen der Struwwelpeter-Sammlung von Heinrich Hoffmann}

\begin{abstract}
Der Artikel ist eine vergleichende Analyse des Motiv des Weinens in drei Übersetzungen von Heinrich Hoffmanns Struwwelpeter ins Polnische. Ziel war es, die gesammelten Daten zu interpretieren (was darauf hindeutet, dass Wörter, die sich auf das Motiv des Weinens beziehen, in allen Übersetzungen deutlich häufiger vorkommen als im Original) und sie mit den Strategien polnischer Übersetzer der in früheren Studien beschriebenen Arbeiten, insbesondere der Arbeiten von Joanna Dybiec-Gajer, in Verbindung zu bringen. Ihre lexikalischen und syntaktischen Entscheidungen und die angewandten Ausschmückungen und Transformationen deuten auf einen engen Zusammenhang mit den Kontexten, in denen das Motiv des Weinens erscheint, und den allgemeinen Merkmalen einer bestimmten Übersetzung/Adaption hin, insbesondere mit der Tendenz, die didaktische oder verspielte Funktion $\mathrm{zu}$ betonen, und andererseits mit den projizierten Reaktionen des kindlichen Lesers: von
\end{abstract}


Angst über Empathie bis hin zur Lektüre „mit einem Augenzwinkern“. Der Artikel stellt auch kurz die Geschichte der Sammlung Struwwelpeter in Polen über 160 Jahre seit der ersten, anonymen Veröffentlichung des Buches mit dem Titel Złota różdżka sowie die wichtigsten Stränge der polnischen Forschung zu diesem Werk vor. Zudem wird über die Interpretationen von Struwwelpeter und Złota różdżka berichtet, die in der polnischen Literatur und Literaturkritik funktionieren, sowie über das in diesem Zusammenhang beschriebene Problem der Gleichsetzung der Übersetzung (die in Wirklichkeit eine Adaption ist) mit dem Original.

Schlüsselwörter: Struwwelpeter, Złota różdżka, Übersetzung, Adaption, ludische Funktion, Didaktismus, Empathie. 